University of Nebraska - Lincoln

DigitalCommons@University of Nebraska - Lincoln

\title{
Molasses enhanced phyto and bioremediation treatability study of explosives contaminated Hawaiian soils
}

Krishna M. Lamichhane

University of Hawaii, lamichha@hawaii.edu

Roger W. Babcock Jr.

University of Hawaii, rbabcock@hawaii.edu

Steve J. Turnbull

US Army Garrison, HI, steve.j.turnbull@us.army.mil

Susan Schenck

Hawaii Agriculture Research Center, sschenck@harc-hspa.com

Follow this and additional works at: https://digitalcommons.unl.edu/usarmyresearch

Lamichhane, Krishna M.; Babcock, Roger W. Jr.; Turnbull, Steve J.; and Schenck, Susan, "Molasses

enhanced phyto and bioremediation treatability study of explosives contaminated Hawaiian soils" (2012).

US Army Research. 202.

https://digitalcommons.unl.edu/usarmyresearch/202

This Article is brought to you for free and open access by the U.S. Department of Defense at DigitalCommons@University of Nebraska - Lincoln. It has been accepted for inclusion in US Army Research by an authorized administrator of DigitalCommons@University of Nebraska - Lincoln. 


\title{
Molasses enhanced phyto and bioremediation treatability study of explosives contaminated Hawaiian soils
}

\author{
Krishna M. Lamichhane ${ }^{\mathrm{a}, 1}$, Roger W. Babcock Jr. ${ }^{\mathrm{b}, *}$, Steve J. Turnbull ${ }^{\mathrm{c}, 2}$, Susan Schenck ${ }^{\mathrm{d}, 3}$ \\ a University of Hawaii, Department of Civil and Environmental Engineering, 2540 Dole Street, Holmes 283, Honolulu, HI 96822, USA \\ ${ }^{\mathrm{b}}$ University of Hawaii, Department of Civil and Environmental Engineering, 2540 Dole Street, Holmes 383, Honolulu, HI 96822, USA \\ ' Directorate of Public Works, US Army Garrison, HI 572 Santos Dumont Ave, 3rd Floor, Schofield Barracks, HI 96857, USA \\ d Hawaii Agriculture Research Center, 99-193 Aiea Heights Drive, Suite 300, Aiea, HI 96701, USA
}

\section{H I G H L I G H T S}

- Natural degradation of RDX is very slow and its release into the environment is a concern.

- Molasses enhances biodegradation of RDX and complete degradation occurred within few weeks.

- Low molasses dose of 1:40 (molasses to water ratio) was as effective as the higher dose (1:20).

- The combination of Guinea Grass (Panicum maximum) and molasses did not improve RDX degradation.

- Addition of molasses to soil in army training ranges can prevent migration of RDX to groundwater and off-site.

\section{A R T I C L E I N F O}

\section{Article history:}

Received 29 June 2012

Received in revised form 20 October 2012

Accepted 20 October 2012

Available online 2 November 2012

\section{Keywords:}

RDX

HMX

Bioremediation

Phytoremediation

Green house study

\begin{abstract}
A B S T R A C T
A 15-week treatability study was conducted in a greenhouse to evaluate the potential effects of molasses on the bioremediation and phytoremediation potential of Guinea Grass (Panicum maximum) for treating energetic contaminated soil from the open burn/open detonation area of the Makua Military Reservation, Oahu, HI (USA). The energetics in the soil were royal demolition explosive (RDX) and high-melting explosive (HMX). Among the 6 treatments employed in this study, enhanced removal of RDX was observed from treatments that received molasses and went to completion. The RDX degradation rates in treatments with molasses diluted 1:20 and 1:40 were comparable suggesting that the lower dose worked as well as the higher dose. Treatments without molasses degraded RDX slowly and residuals remained after 15 weeks. The bacterial densities in molasses-treated units were much greater than those without molasses. Phytoremediation alone seems to have little effect on RDX disappearance. For HMX, neither bioremediation nor phytoremediation was found to be useful in reducing the concentration within the experimental period. The concentrations of nitrogen and phosphorous in the soil did not change significantly during the experiment, however, a slight increase in soil $\mathrm{pH}$ was observed in all treatments. The study showed that irrigating with diluted molasses is effective at enhancing RDX degradation mainly in the root zone and just below it. The long term sustainability of active training ranges can be enhanced by bioremediation using molasses treatments to prevent RDX deposited by on-going operations from migrating through the soil to groundwater and off-site.
\end{abstract}

(c) 2012 Elsevier B.V. All rights reserved.

\section{Introduction}

Modern explosives or energetic materials like $\operatorname{RDX}\left(\mathrm{C}_{3} \mathrm{H}_{6} \mathrm{~N}_{6} \mathrm{O}_{6}\right.$, research department explosive also called royal demolition

\footnotetext{
* Corresponding author. Tel.: +1 808956 7298; fax: +1 8089565014

E-mail addresses: lamichha@hawaii.edu (K.M. Lamichhane), rbabcock@hawaii.edu (R.W. Babcock Jr.), steve.j.turnbull@us.army.mil

(S.J. Turnbull), sschenck@harc-hspa.com (S. Schenck).

1 Tel.: +1 8089567358 .

2 Tel. +18086562878

3 Tel.: +1 8084865386 .
}

explosive), $\mathrm{HMX}\left(\mathrm{C}_{4} \mathrm{H}_{8} \mathrm{~N}_{8} \mathrm{O}_{8}\right.$, high-melting explosive), TNT $\left(\mathrm{C}_{7} \mathrm{H}_{5} \mathrm{~N}_{3} \mathrm{O}_{6}\right.$, trinitrotoluene) and DNT (C7H6N2O4, dinitrotoluene) are polynitro organic compounds with the potential for selfoxidation. Among 20 different chemicals, RDX and HMX are the most powerful and common energetic compounds used by the military in conventional munitions [1]. RDX is an environmental pollutant that can be biotransformed by indigenous soil microorganisms, photo-oxidized by sunlight, and/or migrate through subsurface soil to cause groundwater contamination [2]. RDX has been detected in leachate waters below live fire hand grenade ranges and in surface waters leaving range impact areas [3,4]. Live-fire military training can deposit millimeter-sized particles of 
explosives on surface soils even when rounds explode as intended [5]. These particles dissolve over an extended period of time and this is the primary mechanism for the transport and dissemination of energetics throughout the environment [6]. EPA (1998) [7] classifies RDX as a possible human carcinogen class $C$ and may cause generalized seizures [8]. HMX may be harmful to the central nervous system [9].

The 4249 acre Makua Military Reservation (MMR) on Oahu has been in operation since the 1940 s as a combined-arms live-fire exercise training site. MMR contains an 18 acre open burning/open detonation (OB/OD) area that was used for the disposal of ordnance from the 1960s through the early 1990s. The MMR contains extensive coverage with Guinea grass (Panicum maximum). The energetics RDX and HMX have been detected in the MMR (OB/OD) soils and vadose zone pore water at concentrations above EPA Region 9 Preliminary Remediation Goals (PRGs). RDX concentrations up to $9 \mathrm{mg} / \mathrm{kg}$ ( $>5.5 \mathrm{mg} / \mathrm{kg}$ residential soils $\mathrm{PRG}$ ) were observed in MMR soil [10]. The vadose zone shallow pore water contained an average of 5,712 $\mu \mathrm{g} / \mathrm{l}$ (range: $27-21,000 \mu \mathrm{g} / \mathrm{l}$ ) of RDX and $1081 \mu \mathrm{g} / \mathrm{l}$ (range 3.8-2700 $\mu \mathrm{g} / \mathrm{l}$ ) of HMX. These values are generally higher than the Region 9 PRG of $1800 \mu \mathrm{g} / \mathrm{l}$.

Hawaiian soils are acidic ( $\mathrm{pH}$ 4.0-7.3), have a net positive charge (unlike most tropical soils), and high iron and aluminum content. The percent saturation of these soils is high under field conditions (70-100\%). The OB/OD area soils have high levels of lead $(\mathrm{Pb})$, moderately elevated levels of zinc ( $\mathrm{Zn}$ ) and chromium $(\mathrm{Cr})$ compared to levels present in the parental volcanic rocks.

Bioremediation has been successfully employed to treat certain RDX and HMX contaminated soils [11] by creating reducing conditions using a supplemental carbon source such as starch or molasses. Various microorganisms isolated from RDX contaminated soil were able to degrade $\operatorname{RDX}[12,13]$. The degradation of RDX can occur via the two-electron reductive pathway (Nitroso route) and via denitration [14,15]. Enterobacteria, and Escherichia coli are some of the bacteria that can degrade RDX using the reductive degradation pathway. In the reductive pathway RDX is reduced to hexahydro-1-nitroso-3,5-dinitro-,3,5triazine (MNX) and then hexahydro-,3-dinitroso-5-nitro-1,3,5-triazine (DNX) and hexahydro1,3,5-trinitroso-1,3,5-triazine (TNX). The denitration pathway can be aerobic or anaerobic. Bacteria like Klebsiella pneumoniae can denitrate RDX anaerobically [15] and Williamsia, and Gordonia can denitrate RDX aerobically [16].

Phytoremediation is evolving as an inexpensive remediation technology for energetics contaminated soil $[17,18]$. Vegetation increases the amount of organic carbon in the soil, stimulates microbial activity in the root zone, reverses the downward migration of contaminants by transpiring considerable amounts of water, and improves aeration of soil $[19,20]$. There is some evidence in the literature of beans and other plants taking up RDX [21,22]. Our preliminary studies showed that Guinea grass from MMR could uptake small amounts of RDX and HMX [23,24].

The objective of the treatability study was to evaluate the potential of Guinea grass as a phytoremediation plant and molasses as a bioremediation carbon source to effectively treat RDX in the unique chemistry of Hawaiian soils. Molasses is readily available and relatively inexpensive in Hawai'i and is also known to enhance the growth of Guinea grass potentially assisting both bioremediation and phytoremediation. Although previous studies have demonstrated the applicability of phytoremediation and biodegradability of RDX and HMX, no work had been done with Guinea grass or with Hawaiian soils. Also in Hawaii, the contamination extends well below the root zone in the pore water and because the substratum is highly permeable, once the contaminants pass the carbon rich root zone (upper $30 \mathrm{~cm}$ ) the risk for contamination of groundwater is increased [25].

\section{Materials and methods}

\subsection{Experimental design}

The 15-week treatability study was conducted in the Hawaiian Agricultural Research Center greenhouse at Kunia, Oahu based on a randomized complete block design. There were 54 experimental units (plastic pots) of 4 gallons capacity each. Each experimental unit (pot) with 9 replications received one of the 6 treatments: (A) bare soil receiving irrigation; (B) bare soil not receiving irrigation; (C) Guinea grass, seeded in the pots; (D) molasses added at a 1:20 dilution; (E) molasses added at a 1:40 dilution; and (F) both Guinea grass and molasses added at 1:20 dilution. Molasses was added to treatments D-F as a $500 \mathrm{ml}$ soil drench every 2 weeks.

Approximately 32 cubic feet of soil was excavated from a location adjacent to the OB/OD area at MMR. Soil was screened through a $9.5-\mathrm{mm}$ screen and further homogenized using a cement mixer. Six grab samples of the homogenized soil were analyzed for the background concentration of energetic compounds before pots were filled. The RDX and HMX concentrations were nonhomogeneous with RDX varying from 0.17 to $1.48 \mathrm{mg} / \mathrm{kg}$ (mean 0.69 , standard deviation (SD) 0.53) and HMX varying from 0.03 to $0.05 \mathrm{mg} / \mathrm{kg}$ (mean 0.04 , SD 0.01). All pots were inoculated with additional energetic compounds at the beginning using spiked water containing $4.96 \mathrm{mg} / \mathrm{l} \mathrm{RDX}$ and $0.35 \mathrm{mg} / \mathrm{l} \mathrm{HMX}$ giving an addition of $0.60 \mathrm{mg} / \mathrm{kg}$ RDX and $0.042 \mathrm{mg} / \mathrm{kg}$ HMX to each pot. The estimated initial concentrations were therefore $1.29 \mathrm{mg} / \mathrm{kg} \mathrm{RDX}$ and $0.082 \mathrm{mg} / \mathrm{kg}$ HMX. The background concentrations of RDX daughter products (MNX, DNX and TNX) were not measured. The irrigation with the spiked water at the beginning and with clean water thereafter was intended to reach soil field capacity but not to the point of drainage. Similar sized Guinea grass plants were planted in 18 experimental units (treatments $\mathrm{C}$ and $\mathrm{F}$ ).

Among the six treatments, treatments $\mathrm{A}$ and $\mathrm{B}$ acted as controls. Treatment A (bare soil with irrigation) simulated natural attenuation of the energetic compounds in the $\mathrm{OB} / \mathrm{OD}$ soil during the wet season. Treatment B (bare soil, no irrigation) simulated the condition of the contaminated soil during the dry season. Comparison between these two controls could show the effect of precipitation on the natural attenuation processes of the energetic compounds in the soil.

\subsection{Sampling protocol}

Soil samples were analyzed for energetics at weeks 1, 2, 4, 8 and 15. One composite sample for each treatment ( 9 pots) was collected at the end of weeks 1 and 2 by grabbing small (2-3 g) aliquots from the top three inches of each pot (using a $6 \mathrm{~mm}$ cork borer). Eighteen pots ( 3 pots from each treatment) were sacrificed at the end of weeks 4,8 , and 15 . This left 36 pots from week 5 to week 8 and 18 pots from week 9 to week 15 . Triplicate composite soil samples consisting of nine sub-samples were collected from each sacrificed pot during week 4 , week 8 and week 15 . The contents of sacrificed pots were spread out evenly on a tarp with a 3-by-3 grid, from which three soil composites were prepared by randomly grabbing soil from all 9 grid squares. After collecting samples, the remaining soil was placed back into the pot and artificial leachate was induced by adding 41 of clean water. The induced leachate was sampled to determine whether residual energetics and/or their degradation products were leachable.

To estimate bacteria densities, small samples of soil were collected from the surface of each pot at weeks 2, 4, 6, 8, 12 and 14 and the samples from all replicates of each treatment were combined and mixed. $1 \mathrm{~g}$ of the mixed soil from each treatment was used to estimate the bacterial population densities. Eight samples of plant tissues (roots and shoots) were collected (from treatments C and F) 
at the end of 4 and 15 weeks to determine any plant uptake of RDX and HMX.

\subsection{Sample analyses}

A total of 180 soil samples were analyzed for RDX, HMX, and nitroso metabolites of RDX (MNX, DNX, and TNX). And 51 leachate and 8 plant tissue samples were analyzed for RDX and HMX. The chemical and physical parameters were analyzed in the University of Hawai'i Water Resources Research Center lab. The water and soil samples for energetic were analyzed by EPA Method 8330 utilizing a CN reverse phase High Pressure Liquid Chromatography (HPLC) column, with a C18 column for confirmation. Soil extractions were conducted using the ultrasonic extraction method contained in EPA Method 8330. A modification was that we used $4 \mathrm{~g}$ soil samples instead of $2 \mathrm{~g}$ in the method; we also used $20 \mathrm{ml}$ acetonitrile instead of $10 \mathrm{ml}$ in the method to maintain the same ratio. The detection limits for all energetics was $0.01 \mathrm{mg} / \mathrm{kg}$ in soil samples and $0.001 \mathrm{mg} / \mathrm{l}$ in liquid (leachate) samples as per method 8830A. Soil pH was measured by EPA method 150.2, total nitrogen by dry combustion method (Leco CN2000 instrument) and total phosphorus by using modified Truog method developed for tropical soils [26]. Soil bacteria density (colony forming units, cfu) was measured using the procedure of Schenck (see Supporting Information, Fig. S1) [27]

Supplementary material related to this article found, in the online version, at http://dx.doi.org/10.1016/j.jhazmat.2012.10.043.

Soil samples from MMR were also analyzed for aerobic RDX degraders. Soil samples were suspended in sterile water and placed on a rotary shaker for $10 \mathrm{~min}$ followed by centrifugation at $1500 \mathrm{rpm}$ and the supernatant poured off. This was repeated three times to eliminate soil organic matter. Soil samples were then placed in liquid medium containing RDX as the sole nitrogen source and glucose as the carbon source and allowed to grow for five days with shaking. Subsequently, samples of the growth medium were spread on petri plate of RDX medium and colonies grew from colony forming units. These were transferred several more times and only those aerobic microorganism species able to live with RDX as the only nitrogen source were isolated.

Plant materials were extracted into 100\% acetonitrile using a Dionex ASE 200 accelerated solvent extractor. ASE 200 conditions were: $1500 \mathrm{psi}, 100^{\circ} \mathrm{C}$, preheat time $5 \mathrm{~min}$, static time $5 \mathrm{~min}$ and flush volume $60 \%$. Sample cleanup procedure included $2 \mathrm{ml}$ of sample extract added to an acetonitrile-rinsed Forisil SPE cartridge on a vacuum manifold. Two additional $\mathrm{ml}$ of acetonitrile were added to the cartridge and collected together with the sample. This effluent was then diluted $1: 1$ with the calcium chloride $\left(\mathrm{CaCl}_{2}\right)$ reagent specified in EPA method 8330A (same as for soil extracts), then filtered using a $0.45 \mu \mathrm{m}$ syringe filter. The extracts were then analyzed for energetics using a Thermo Finnigan Surveyor HPLC with Photodiode array detector monitoring $230 \mathrm{~nm}$ and $254 \mathrm{~nm}$ wavelengths.

\section{Results and discussion}

\subsection{Bacterial population measurements}

The bacterial densities in soil samples from each treatment were determined (Fig. 1). Much higher densities were present in treatments D-F compared to treatments A-C during the entire 15-week experimental period indicating that molasses enhances bacterial activity in energetics contaminated soil.

All molasses amended treatments experienced bacteria density increase during the first 6 weeks although the highest densities appeared at different times for the different treatments. The maintenance of higher bacteria densities in treatment $\mathrm{F}$ with Guinea

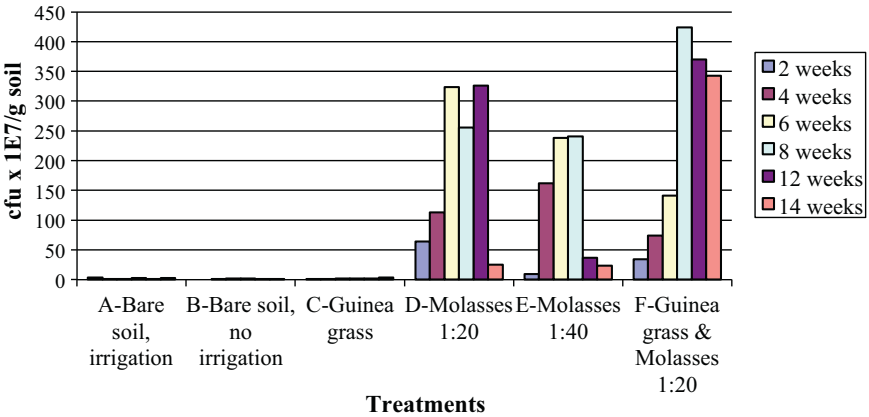

Fig. 1. Average bacteria densities for each treatment over time in near-surface soil samples.

grass throughout the entire 14 weeks may be due to the presence of root exudates or to the plant's ability to hold soil water. The drop in bacterial density for treatment $\mathrm{D}$ at week 14 and treatment $\mathrm{E}$ at week 12 very likely indicates that the molasses had been used up. The molasses dilution of 1:40 (lower molasses concentration) enhanced the bacterial density nearly as much as the $1: 20$ dilution (higher molasses concentration). Five different aerobic bacteria species able to use RDX as sole nitrogen source were isolated.

\subsection{Energetics removal}

The change in concentration of RDX, HMX, and RDX degradation products in soil, leachate and plant tissue samples were monitored.

\subsubsection{RDX transformations in soil}

RDX was detectable in treatments A-C (Group 1 ) and either not detected or nearly so in treatments D-F (Group 2 ) in weeks 4,8 , and 15 when pots were sacrificed in triplicate (Fig. 2) and triplicate composite samples collected from each pot (source of error bars). This indicates that RDX was mostly degraded in the Group 2 treatments very rapidly (before the first pots were sacrificed at 4 weeks). Small volume surface samples were collected from all pots and composited by treatment in weeks 1 and 2 for bacteria densities. These samples were analyzed for RDX to get an idea of what happened prior to the 4-week major sampling event. Although the data show a large variability $(0.25-4 \mathrm{mg} / \mathrm{kg}$ in week 1$)$, they indicate that RDX remained in all treatments in week 1 , that it decreased dramatically by week 2 in the Group 2 treatments, and that it did not decrease in the Group 1 treatments from week 1 to week 2 . The large variability of RDX concentration is assumed to be due to the nature of the field contamination which consists of particles of RDX. If a sample contains a particle or several particles of pure RDX, it will have a

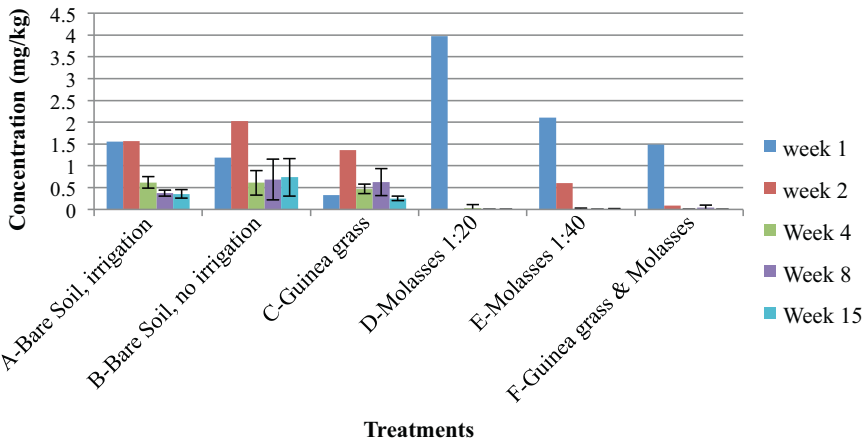

Fig. 2. Average RDX concentration in soil over time for each treatment. Weeks and 2 represent 3 near-surface grab samples and weeks 4,8 , and 15 represent 9 composite samples ( 3 each from 3 sacrificed pots). 


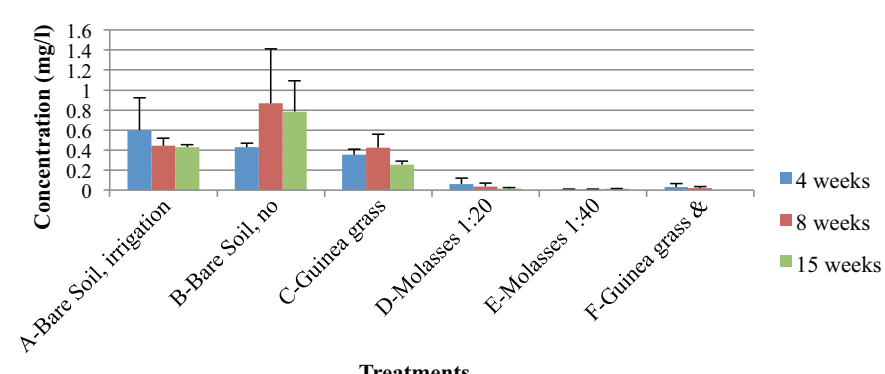

Fig. 3. Average RDX concentration in artificially induced leachate collected from sacrificed pots. Each bar represents 3 sacrificed pots for the same treatment.

high concentration, and if it does not contain any particles, it will have a much lower concentration. This phenomenon has been cited in the literature [5,28,29].

These results indicate that the Group 2 treatments are more efficient in removing RDX from soil and that biodegradation was very rapid (mostly occurring in the second week). The error bars in Group 1 for week 15 overlapped; therefore there were no significant differences in RDX concentration for the three treatments during the experiment. Comparing only the data from week 4 and week 15 , treatment $A$ and $C$ did show a lower RDX concentration at week 15 . For treatment $B$, the overlapping error bars indicate no significant differences among the data from week 4, week 8 and week 15. These results (comparing $A$ and $B$ ) indicate that irrigation can improve RDX attenuation, probably by sustaining microbial activity. The results for treatment $C$ with Guinea grass did not show a more significant RDX reduction than the irrigated bare soil. This is interpreted to mean that phytoremediation alone (without molasses addition) did not enhance soil-based natural attenuation. The concentrations of RDX degradation products MNX, DNX, TNX in extracts from soil samples were all below detection limit during the 15-week experiment.

\subsection{2. $R D X$ in leachate}

No naturally formed leachate was observed or collected from the 54 pots during the treatability study. The presence of RDX in induced leachate (from sacrificed pots) could indicate the possibility of ground water contamination through leaching (Fig. 3). Similar to the composite soil samples, leachate from Group 2 had significantly lower RDX concentrations compared to that of Group 1. The lower concentrations in Group 2 can be attributed to enhanced biodegradation due to molasses addition. There appears to be little difference in RDX concentration among the treatments within each group. The higher dilution (1:40) of molasses appears to have the same effect as the lower dilution (1:20). In Group 1, irrigation and Guinea grass each seem to have a positive effect on the RDX attenuation process (compared to non-irrigation). Also, Guinea grass does not appear to affect natural attenuation greater than just irrigation of bare soil.

\subsubsection{RDX degradation products in induced leachate}

Unlike in the composite soil samples, RDX degradation products were observed in some of the leachate samples providing evidence of biodegradation. MNX showed up in leachate from Group 1 treatments (Fig. 4) with concentrations in the range of $0.002-0.01 \mathrm{mg} / \mathrm{kg}$. MNX concentrations in leachate from Group 2 treatments are lower than those in Group 1, but still present. This could be interpreted as accumulation of the first biotransformation product (MNX) in Group 1 treatments due to slower biodegradation as well as more rapid biodegradation in Group 2 treatments. DNX, the degradation product of MNX was not present in any samples at 4 weeks but was found in many of the leachate samples (Fig. 5) beginning in week 8 . TNX, the degradation product of DNX, was observed

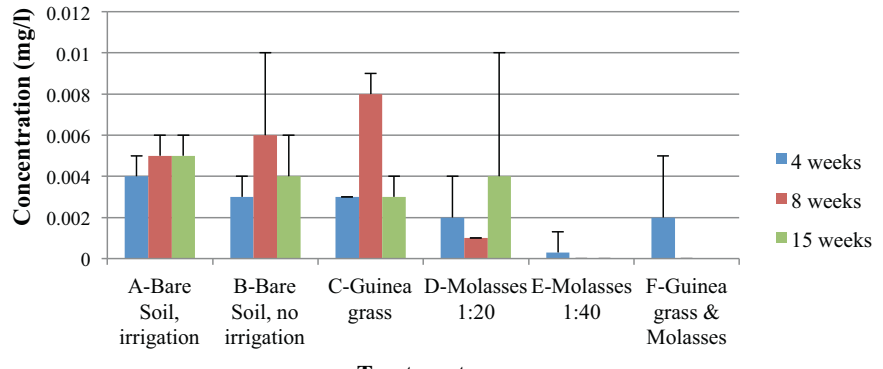

Fig. 4. Average MNX concentration in artificially induced leachate collected from sacrificed pots. Each bar represents 3 sacrificed pots for the same treatment.

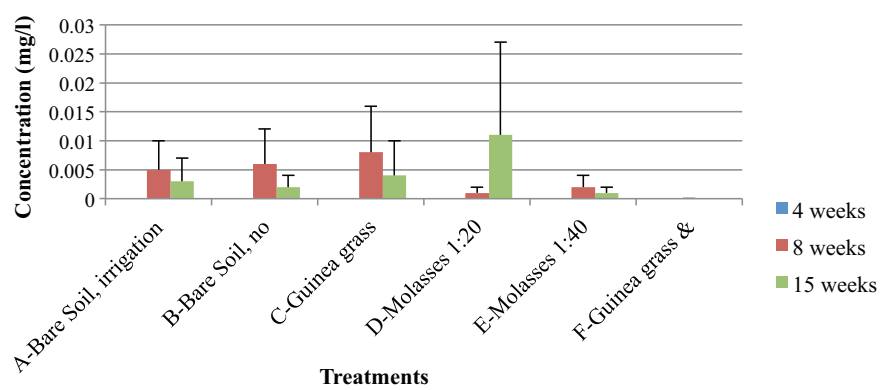

Fig. 5. Average DNX concentration in artificially induced leachate collected from sacrificed pots. Each bar represents 3 sacrificed pots for the same treatment.

in only a few samples from treatment B (bare soil no irrigation) probably indicating that it is readily degraded to simpler compounds (Fig. 6) and does not accumulate in molasses treated pots. Overall, the leachate data indicate that in Group 1 treatments, less RDX is degraded in 15 weeks, and more MNX, DNX, and TNX remain in the soil at all sampling events, compared to Group 2 treatments. This indicates that addition of molasses enhanced biodegradation of RDX and its daughter products over the 15-week experiment.

\section{3. $H M X$}

Although HMX remediation was not a study objective, its presence was monitored as it was a known contaminant at the site. HMX was present in both soil (Fig. 7) and leachate (Fig. 8) and the concentrations did not change significantly over time or with different treatments. The final concentration of HMX in the soil was in the range of $0.06-0.213 \mathrm{mg} / \mathrm{kg}$ and that in the induced leachate was in the range of $0.015-0.091 \mathrm{mg} / \mathrm{l}$. The similar HMX concentrations in leachate from all treatments also indicate that irrigation, Guinea grass, and molasses did not enhance the leaching potential of HMX. The results suggest that neither Guinea grass nor molasses had a significant effect on HMX degradation within the

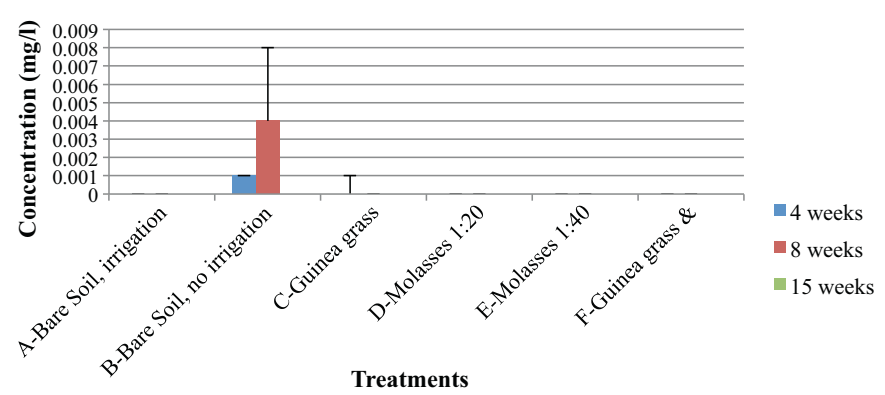

Fig. 6. Average TNX concentration in artificially induced leachate collected from sacrificed pots. Each bar represents 3 sacrificed pots for the same treatment. 


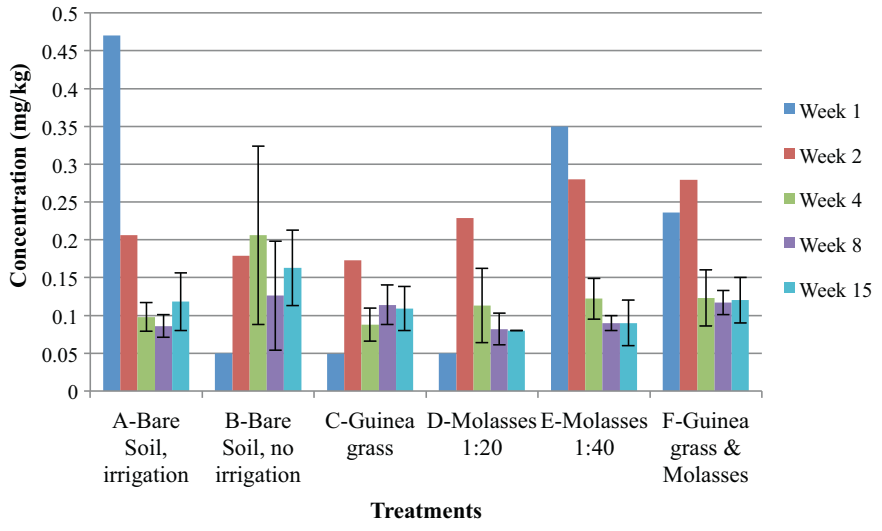

Fig. 7. Average HMX concentration in soil over time for each treatment. Weeks 1 and 2 represent 3 near-surface grab samples and weeks 4,8 , and 15 represent 9 composite samples ( 3 each from 3 sacrificed pots).

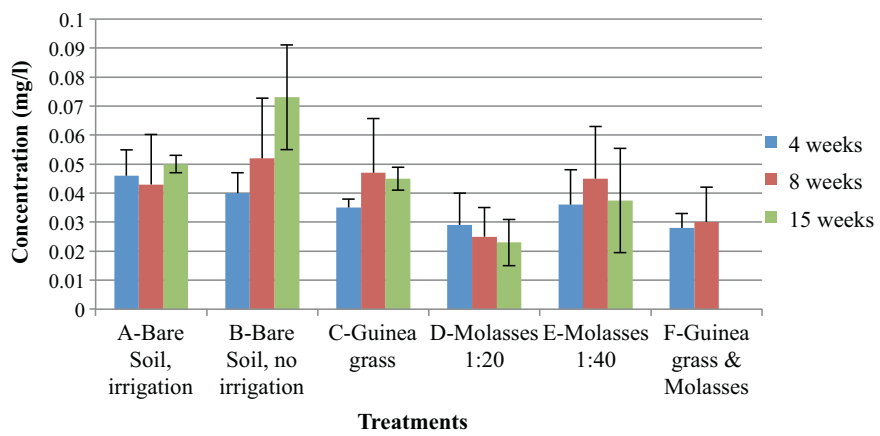

Fig. 8. Average HMX concentration in artificially induced leachate collected from sacrificed pots. Each bar represents 3 sacrificed pots for the same treatment.

experimental period. This does not mean that HMX is nonbiodegradable in Hawaiian soils. It is possible that biodegradation of HMX may not begin until after RDX degradation is complete [30], however, this study was designed for only 15 weeks.

\subsection{Nitrogen, phosphorus, and pH measurements}

Soil concentrations of nitrogen $(497 \mathrm{mg} / \mathrm{kg}$ average in excavated soil) and phosphorus ( $7.2 \mathrm{mg} / \mathrm{kg}$ ) did not change appreciably during the study, indicating that there were adequate amounts of these nutrients in the soil and supplements would not be required in full-scale operations. The soil $\mathrm{pH}$, however, increased slightly (from approximately 5.0 to approximately 5.5) in all pots during the experiment. This small increase in soil pH should not cause adverse effects.

\subsection{Energetics in plant tissues}

Plant tissues from treatments with Guinea grass were collected at weeks 4 and 15 and then analyzed for energetic compounds. RDX and HMX were found in most plant tissue samples but none of the breakdown products were observed. Plant tissues from treatment C contained $1.67 \mathrm{mg} / \mathrm{kg}$ RDX at week 4 and increased to $2.83 \mathrm{mg} / \mathrm{kg}$ at week 15. Plant tissues from treatment F contained $<0.1 \mathrm{mg} / \mathrm{kg}$ RDX at week 4 and this increased to $3.37 \mathrm{mg} / \mathrm{kg}$ RDX at week 15 . This indicates that the Guinea grass was able to adsorb/absorb some RDX and HMX from the soil.

\section{Conclusions}

The study showed that irrigating with molasses is effective at enhancing RDX degradation mainly in the root zone and just below it in Hawaiian soils. The unique characteristics such as acidity and positive charge, high iron and aluminum did not hinder this approach. Data showed that molasses significantly increased bacteria densities. The low concentration of RDX in both soil and leachate samples and the presence of known RDX degradation products indicate that RDX in soil was removed by biodegradation, rather than leaching enhancement (washout). The transformation of RDX with added molasses occurred in weeks as compared to months without molasses. The lower dose of molasses (1:40 dilution) is recommended for future studies as it was nearly as effective as the higher dose (1:20 dilution) at promoting increased bacteria densities and enhanced RDX degradation. The combination of Guinea grass with molasses seemed to only slightly enhance RDX removal under the conditions of this study, however, it did sustain the highest bacteria densities through the end of the study period. Guinea grass is good for erosion control and grows well with molasses and is recommended in combination with molasses irrigation for range management. The long term sustainability of training ranges like MMR can be enhanced by treating active training areas with molasses to prevent migration of RDX through the soil to groundwater and off-site.

\section{Acknowledgements}

This green house treatability study is the part of the project entitled "Enhanced Degradation of Energetic Contamination in Live Fire Ranges Located in Tropical Environments (Contract No. W912HQ06-C-0049)". This project was funded under the Environmental Security Technology Certification Program (ESTCP) and U.S. Army Garrison Hawai'i. The authors would also like to acknowledge Nicole Scheman for her help on this study.

\section{References}

[1] J.C. Spain, J.B. Hughes, H.-J. Knackmuss, in: J.C. Spain (Ed.), Biodegradation of Nitroaromatic Compounds and Explosives, Lewis Publishers, CRC Press LLC, Boca Raton, Florida, USA, 2000.

[2] A. Halasz, C. Groom, E. Zhou, L. Paquet, C. Beaulieu, S. Deschamps, A. Corriveau, S. Thiboutot, G. Ampleman, C. Dubois, J. Hawari, Detection of explosives and their degradation products in soil environments, J. Chromatogr. A 963 (2002) 411-418.

[3] T.F. Jenkins, J.C. Pennington, T.A. Ranney, T.E.M.P.H. Berry Jr., M.E. Walsh, A.D. Hewitt, N.M. Perron, L.V. Parker, C.A. Hayes, E.G. Wahlgren, Characterization of Explosives Contamination at Military Firing Ranges, ERDC/CRREL TR-01-5 Army Engineer Research and Development Center, 2001.

[4] J.C. Pennington, A. Jenkins, G.S. Thiboutot, J.M. Brannon, J. Lynch, T.A. Ranney, J.A. Stark, M.E. Walsh, J. Lewis, C.A. Hayes, J.E. Mirecki, A.D. Hewitt, N. Perron, D. Lambert, J. Clausen, J.J. Delfino, Distribution and Fate of Energetics on DoD Test and Training Ranges, Interim Report 2. ERDC TR-02-08, 2002.

[5] D. Kalderis, A.L. Juhasz, R. Boopathy, S. Comfort, Soils contaminated with explosives: environmental fate and evaluation of state-of the-art remediation processes (IUPAC Technical Report), Pure Appl. Chem. 83 (2011) 1407-1484.

[6] J.C. Lynch, J.M. Brannon, J.J. Delfino, Dissolution rates of three high explosive compounds: TNT, RDX, and HMX, Chemosphere 47 (2002) 725-734.

[7] EPA, Integrated risk information system, in: Reference Dose for Chronic Oral Exposure (RfD), Environmental Protection Agency, 1998.

[8] L.R. Williams, V. Aroniadou-Anderjaska, F. Qashu, H. Finne, V. Pidoplichko, D.I Bannon, M.F. Braga, RDX binds to the GABA(A) receptor-convulsant site and blocks GABA(A) receptor-mediated currents in the amygdala: a mechanism for RDX-induced seizures, Environ. Health Perspect. 119 (2011) 357-363.

[9] CDC, Toxicological profile for HMX, in: U.S.D.o.H.a.H. Services (Ed.), Center for Disease Control, Agency for Toxic Substances and Disease Registry, 1997.

[10] K.J. Daubel, Concerning results of analysis performed on ten soil samples from Fort Shafter, Project No. 37-26-0484-85, Letter to Commander, U.S. Army Environmental Hygiene Agency, Fort Shafter, Hawaii, 1985

[11] S.B. Funk, D.J. Roberts, D.L. Crawford, R.L. Crawford, Initial-phase optimization for bioremediation of munition compound-contaminated soils, Appl. Environ. Microbiol. 59 (1993) 2171-2177. 
[12] P.R. Binks, S. Nicklin, N.C. Bruce, Degradation of hexahydro-1,3,5-trinitro-1,3,5 triazine (RDX) by Stenotrophomonas maltophilia PB1, Appl. Environ. Microbiol. 61 (1995) 1318-1322.

[13] N.V. Coleman, D.R. Nelson, T. Duxbury, Aerobic biodegradation of hexahydro1,3,5-trinitro-1,3,5-triazine (RDX) as a nitrogen source by a Rhodococcus sp., strain DN22, Soil Biol. Biochem. 30 (1998) 1159-1167.

[14] F.H. Crocker, K.J. Indest, H.L. Fredrickson, Biodegradation of the cyclic nitramine explosives RDX, HMX, and CL-20, Appl. Microbiol. Biotechnol. 73 (2006) 274-290.

[15] J.S. Zhao, A. Halasz, L. Paquet, C. Beaulieu, J. Hawari, Biodegradation of hexahydro-1,3,5-trinitro-1,3,5-triazine and its mononitroso derivative hexahydro-1-nitroso-3,5-dinitro-1,3,5-triazine by Klebsiella pneumoniae strain SCZ-1 isolated from an anaerobic sludge, Appl. Environ. Microbiol. 68 (2002) 5336-5341.

[16] K.T. Thompson, F.H. Crocker, H.L. Fredrickson, Mineralization of the cyclic nitramine explosive hexahydro-1,3,5-trinitro-1,3,5-triazine by Gordonia and Williamsia spp., Appl. Environ. Microbiol. 71 (2005) 8265-8272.

[17] S.C. McCutcheon, J.L. Schnoor, Overview of phytotransformation and control of wastes, in: Phytoremediation: Transformation and Control of Contaminants, John Wiley \& Sons Inc., Hoboken, NJ, USA, 2004.

[18] S. Cherian, M.M. Oliveira, Transgenic plants in phytoremediation: recent advances and new possibilities, Environ. Sci. Technol. 39 (2005) 9377-9390.

[19] J.L. Schnoor, L.A. Licht, S.C. McCutcheon, N.L. Wolfe, L.H. Carreira, Phytoremediation of organic and nutrient contaminants, Environ. Sci. Technol. 29 (1995) 318A-323A.

[20] L.C. Davis, S. Castro-Diaz, Q. Zhang, L.E. Erickson, Benefits of Vegetation for Soils with Organic Contaminants, Crit. Rev. in Plant Sciences 21 (5) (2002) 457-491

[21] S.D. Harvey, Fate of the explosive hexahydro-1,3,5-trinitro-1,3,5-triazine (RDX) in soil and bioaccumulation in bush bean hydroponic plants, Environ. Toxicol. Chem. 10 (1991) 845-855.
[22] R. Bhadra, D.G. Wayment, R.K. Williams, S.N. Barman, M.B. Stone, J.B. Hughes, J.V. Shanks, Studies on plant-mediated fate of the explosives RDX and HMX, Chemosphere 44 (2001) 1259-1264.

[23] G. Uehara, Q. Li, R. Uchida, S. Campbell, X. Huang, R. Ogoshi, Phytoremediation of OB/OD Unit at Makua Military Reservation Project (Greenhouse Experiment), College of Tropical Agriculture and Human Resources, University of Hawai' $i$, Honolulu, 2002.

[24] Environet, Makua Phytoremediation Demonstration Project, Consultant Report Prepared for the United States Army Corps of Engineers, 2005.

[25] G. Alavi, M. Chung, J. Lichwa, M. D’Alessio, C. Ray, The fate and transport of RDX, HMX, TNT and DNT in the volcanic soils of Hawaii: a laboratory and modeling study, J. Hazard. Mater. 185 (2011) 1600-1604.

[26] A.S. Ayers, H.H. Hagihara, Available phosphorus in Hawaiian soil profiles, Hawaiian Planters Rec. 54 (1952) 81-89.

[27] S. Schenck, Soil Incorporation of Covercrop Biomass: Effects on Soil Microorganisms and Nitrogen Levels, Diversified Crops Report No. 23, Hawai'i Agriculture Research Center, Aiea, HI, 2003.

[28] M.R. Walsh, S. Taylor, M.E. Walsh, S, Bigl, K. Bjella, T. Douglas, A Gelvin, D. Lambert, N. Perron, S. Saari, Residues from Live Fire Detonations of $155-\mathrm{mm}$ Howitzer Rounds, Cold Regions Research and Engineering Laboratory, US Army Corps of Engineers, Hnover, USA, 2005, p. 29.

[29] S. Taylor, A. Hewitt, J. Lever, C. Hayes, L. Perovich, P. Thorne, C. Daghlian, TNT particle size distributions from detonated $155-\mathrm{mm}$ howitzer rounds, Chemosphere 55 (2004) 357-367.

[30] S. Sagi-Ben Moshe, Z. Ronen, O. Dahan, N. Weisbrod, L. Groisman, E. Adar, R. Nativ, Sequential biodegradation of TNT, RDX and HMX in a mixture, Environ. Pollut. 157 (2009) 2231-2238. 